\title{
REDENOMINASI, NILAI MATA UANG DAN EKSISTENSI EMAS DI ERA COVID-19
}

\author{
Chairul Iksan Burhanuddin, Burhanuddn \\ Universitas Muhammadiyah Makassar \\ Universitas Negeri Makassar \\ e-mail: chairul.iksan@unismuh.ac.id
}

\begin{abstract}
Abstrak
Sulit untuk memahami gejolak perekonomian yang melanda negara Indonesia, apalagi diberbagai belahan dunia. Hal ini berkaitan dengan mewabahnya virus corona atau yang akrab dengan sebutan covid19. Kontraksi perekonomian jelas menyerang diberbagai sektor, mulai dari sektor perdagangan, manufaktur, hingga pasar modal. Permasalahan lainnya yang tak kalah pelik adalah nilai mata uang rupiah yang terus merosot tajam diikuti dengan pergolakan nilai emas yang harganya terus melambung tinggi. Belum lagi isu redenominasi uang rupiah yang terus bergulir dibalik ketidakpastian ekonomi. Penelitian ini memberikan perspektif ekonomi dan esensi yang perlu dibangun dalam berbagai permasalahan dan isu ekonomi yang dihadapi negara Indonesia. Oleh karena itu dari berbagai penjelasan sudut pandang terhadap permasalahan yang dibahas dalam penelitian ini memberikan masukan kepada pihak terkait dalam mengambil keputusan dalam menyikapi permasalahan tersebut. Hasil Penelitian ini diharapkan dapat memberikan informasi dan analisa tentang bagaimana mengambil keputusan dan sikap dibalik masalah ekonomi yang sedang dihadapi saat ini.
\end{abstract}

Kata kunci: Redenominasi, Nilai Mata Uang, Emas, Covid-19.

\section{Abstract}

It is difficult to understand the economic turmoil that has hit Indonesia, especially in various parts of the world. This is related to the outbreak of coronavirus or the familiar one called covid-19. The economic contraction is clearly striking in various sectors, ranging from trade, manufacturing, to capital markets. Another problem that is no less strange is the value of the rupiah which continues to slump sharply followed by the upheaval in the value of gold whose price continues to soar. Not to mention the issue of rupiah redenomination that continues to roll behind economic uncertainty. This research provides an economic perspective and essence that needs to be built on the various economic problems and issues facing the Country of Indonesia. Therefore, from various explanations of the point of view on the issues that are being discussed in this study provide input to the relevant parties in making decisions in addressing the problem. The importance of the results of this study is to provide information and analysis on how to make decisions and attitudes behind the economic problems that are facing today.

Keywords: Redenomination, Currency Value, Gold, Covid-19

\section{PENDAHULUAN}

Tahun 2020 menjadi sebuah titik baru bagi negara Indonesia dan negara lainnya diseluruh dunia dalam menyelesaikan permasalahan dan membangun perekonomian negaranya. Selama ini negara diseluruh dunia hanya fokus menyelesaikan permasalahan ekonomi yang berputar pada inflasi, isu perdagangan, sumberdaya alam, sumberdaya manusia, dan lainnya. Akan tetapi, memasuki semester awal tahun 2020 seluruh dunia bahkan di Indonesia dikagetkan dengan mewabahnya virus corona yang juga disebut sebagai covid-19. Akhirnya negara yang terkena wabah tersebut terfokus dalam menangani penyelesaian dan penanggulangan virus tersebut. Rencana strategis yang semula telah disiapkan untuk implementasi akhirnya harus berubah 360 derajat.

Sebelumnya Kementerian Keuangan dan Bank Indonesia melalui Siaran Pers pada 23 Januari 2013, menyampaikan bahwa Redenominasi rupiah direncanakan 
dilakukan dalam tiga tahapan. Dimana tahap pertama adalah persiapan aturan perundang-undangan, infrastruktur dan strategi komunikasi. Dilanjutkan dengan tahap transisi, melalui pelaksanaan penukaran secara bertahap Rupiah "lama" dan Rupiah "baru" (dual price tagging). Dan, tahap terakhir atau phasing out di mana seluruh transaksi menggunakan Rupiah "baru". Ketiga tahapan tersebut diperkirakan memerlukan waktu sekitar 6 tahun (Kementrian Keuangan 2013).

Rancangan strategis Kementrian Keuangan 2020-2024 yaitu salah satunya fokus pada tahap proses perubahan harga rupiah (Redenominasi) yang nantinya akan segera dibuatkan regulasi oleh pemerintah (BAPENAS Republik Indonesia 2019). Tujuan redenominasi tak lain adalah menyederhanakan banyaknya jumlah digit rupiah. RUU mengenai redenominasi sebelumnya telah dicanangkan sejak tahun 2017 oleh pimpinan Bank Indonesia Agus Martowardjojo. Akan tetapi, redenominasi dapat menjadi pisau bermata dua apabila tidak di analisa dengan tepat. Salah satunya dapat menyebabkan inflasi tingkat tinggi (hiperinflasi) setelah dilakukannya atau diterapkannya kebijakan redenominasi oleha negara terkait.

Rencana redenominasi akhirnya tidak dapat segera di implementasi akibat Covid19 yang kemudian mewabah di Indonesia yang justru mengakibatkan kontraksi ekonomi yang cukup signifikan. Kondisi perekonomian Indonesia yang telah memasuk semester kedua berada pada angka -5,3\% dimana komponen PDB Nasional masih berada kondisi minus walaupun kegiatan ekspor dan impor telah mulai bergerak positif. Selain itu kondisi perekonomian di sektor manufaktur, perdagangan, dan konstruksi masih minus akan tetapi angin segar di sektor pertanian dan pertambangan mulai menunjukkan aktivitas yang positif. Keyakinan konsumen dalam kurva tingkat konsumsi mulai membaik kemudian walaupun dari Badan Pusat Statistik (BPS) menyampaikan bahwa pertumbuhan ekonomi di berbagai wilayah masih dalam kondisi minus (Gathering n.d.).

Wacana redenominasi akan menimbulkan pro dan kontra sebab banyak masyarakat menganggap bahwa redenominasi sama dengan sanering (Lianto and Suryaputra 2012). Redenominasi adalah penyederhanaan nilai nominal mata uang tanpa mengurangi nilai riil mata uang, sebab hanya mengurangi digit (angka nol) (Indonesia 2010). Urgensi dilaksanakannya redenominasi di Indonesia didasari adanya inefisiensi perekonomian, adanya kendala teknis pada operasional kegiatan usaha, dan mendukung ekonomi nasional dalam memasuki era Masyarakat Ekonomi ASEAN (MEA) (Permana 2015). Lebih lanjut nilai nominal yang terlalu besar menunjukkan bahwa suatu negara pernah mengalami kondisi fundamental perekonomian yang kurang baik (Kesumajaya 2011). Ditambah lagi nilai nominal mata uang suatu Negara yang semakin besar disebabkan karena di masa lampau terjadi kesalahan kebijakan yang dilakukan oleh pemerintah. Hal tersebut menyebabkan inefisiensi transaksi perekonomian karena penggunaan mata uang yang relatif kurang efisien. Redenominasi dapat mencegah terjadinya kendala teknis akibat jumlah digit yang besar (Mosley 2005).

Naik turunnya nilai tukar mata uang di pasar uang (apresiasi dan depresiasi) menunjukkan besarnya volatilitas yang terjadi pada mata uang suatu negara dengan mata uang negara lain. Volatilitas yang semakin besar menunjukkan pergerakan kurs yang semakin besar (apresiasi/depresiasi mata uang). Hal ini memberikan gambaran terjadinya overvalued dan undervalued nilai tukar mata uang terhadap mata uang negara lainnya. Manakala nilai tukar mata uang mengalami volatilitas yang ekstrim, maka perekonomian akan mengalami ketidakstabilan baik dari sisi makro dan mikro (Chang, Chou, and Nelling 2000). 
Volatilitas nilai tukar mata uang berpengaruh positif signifikan terhadap permintaan impor di negara-negara Eropa (Jerman, Italia dan dan Yunani) selama tahun 1993-2003 (Mukherjee and Ahuja n.d.). selain itu, pengaruh volatilitas nilai tukar mata uang terhadap aliran perdagangan internasional masih bersifat lack of conclusive and ambiguous (Asseery and Peel 1991). Sebelumnya juga dilakukan penelitian yang memberikan kesimpulan bahwa volatilitas nilai tukar mata uang memiliki pengaruh negatif terhadap permintaan impor Indonesia dari dunia selama tahun 1990-2005 (Suselo, Sihaloho, and Tarsidin 2008).

Pergerakan dalam nilai tukar mata uang memiliki dampak yang berbeda-beda terhadap sektor kegiatan ekonomi, tergantung dari karakteristik khusus dari setiap industri. Karakteristik ini seperti tingkat investasi awal, tingkat substitusi barang dan ketahanan produk (durable good/nondurable good). Sektor kegiatan ekonomi dengan kebutuhan investasi awal yang sedikit akan cenderung untuk lebih sensitif terhadap volatilitas nilai tukar mata uang. Sedangkan sektor ekonomi dengan tingkat kebutuhan investasi awal yang cukup besar tidak sensitif terhadap volatilitas nilai tukar mata uang (Stone, Braccia, and Larson 2005). Marjin pada kejadian hyeteresis akan berbeda dengan sejumlah variabiltas nilai tukar yang terjadi. Nilai tukar mata uang yang terjadi sebelumnya akan digunakan untuk membentuk ekspektasi tentang perubahan nilai tukar. Semakin besar volatilitas nilai tukar sekarang akan berdampak pada semakin besarnya volatilitas di masa depan (Krugman et al. 1999).

Namun disisi lain nilai tukar mata uang yang berada pada posisi rendah (low level) pass through dari nilai tukar dari impor barang membutuhkan penjelasan. Dalam hal ini Baldwin mengajukan penggunaan idea of path dependence di perusahaan yang memiliki keputusan harga secara langsung. Baldwin juga mengemukakan adanya hubungan terbalik antara the size ofthe pass through dan volatilitas dari nilai tukar mata uang (Baldwin and Nino 2006). Sedangkan pemikiran Krugman tidak fokus secara khusus pada pass through elasticity.

Covid-19 tidak hanya menghambat proses redenominasi dan fluktuasi nilai mata uang. Wabah Covid-19 turut memberikan efek pada eksistensi emas diberbagai negara dunia tak terkecuali Indonesia. Kejadian besar ini memberikan efek pula pada nilai beli dan nilai jual emas dalam beberapa bulan terakhir di tahun 2020. Emas pada umumnya menjadi pilihan bagi masyarakat untuk investasi atau bisa menjadi pilihan Save Haven. Beberapa kalangan di masyarakat meyakini bahwa emas memiliki ketahanan khususnya ditengah gejolak inflasi.

Emas memiliki common wisdom "theories" yakni: (1) Orang menganggap emas merupakan simbol kekayaan abadi. Emas merupakan "safe heaven" dalam pasar keuangan, (2) Emas merupakan "nilai lindung inflasi". Emas banyak dipilih sebagai salah satu bentuk investasi karena nilainya cenderung stabil dan naik. Emas adalah alat yang dapat digunakan untuk menangkari inflasi yang kerap terjadi setiap tahunya. Ketika akan berinvestasi, investor memilih investasi yang memiliki tingkat imbal balik yang tinggi dengan risiko tertentu atau tingkat imbal balik tertentu dengan risiko yang rendah. Investasi di pasar saham tentunya lebih beresiko daripada berinvestasi di emas, karena tingkat pengembalianya yang secara umum relatif lebih tinggi dari emas (Fei and Adibe 2010).

Emas dikenal memiliki macam bentuk, yakni: (1) Emas Batangan: Emas batangan adalah emas yang masih dalam bentuk asli dan belum dibentuk. Emas kategori ini memiliki nilai yang lebih tinggi di banding emas yang lainya; (2) Emas Koin: Emas 
koin adalah emas yang sudah dibentuk menjadi koin dan diedarkan ke pasaran untuk dijadikan sebagai salah satu alat ukur dalam setiap transaksi jual beli barang. Emas koin saat ini tidak dianggap representatif lagi sehingga penggunaan emas koin ditiadakan, (3) Emas Perhiasan: Emas perhiasan adalah emas yang sudah dibentuk menjadi perhiasan dan komposisi emasnya sudah mengalami penurunan, karena emas murni sulit dibentuk menjadi perhiasan (Fahmi 2012).

Berbagai dinamika dalam perekonomian khususnya yang terkait dengan Rednominasi, nilai mata uang dan eksistensi emas menjadikan tema yang menarik untuk ditelaah. Oleh karena itu, dalam penelitian ini akan berfokus pada tiga hal tersebut. Penelitian ini diharapkan dapat memberikan perspektif yang berbeda sehingga menambah khasanah dan wawasan baru dalam memahami kondisi perekonomian saat ini dan proyeksi dimasa depan.

\section{METODE PENELITIAN}

Metode Penelitian yang digunakan adalah menggunakan pendekatan kualitatif dengan menerapkan metode riset kepustakaan (Library Research). Riset kepustakaan menggunakan literatur sebagai objek kajian. Data yang digunakan dalam penelitian ini adalah berupa data sekunder, yaitu buku-buku, jurnal-jurnal ilmiah dan informasi lainnya dari internet yang dianggap valid. Sedangkan untuk menjawab permasalahan, penelitian ini akan menggunakan metode content analysis dengan memberikan datadata untuk menjawab permasalahan tersebut.

\section{HASIL DAN PEMBAHASAN}

\section{Hasil}

Dibalik isu redenominasi mata uang rupiah, virus covid-19 justru mempengaruhi nilai mata uang rupiah terhadap dollar Amerika. Perubahan nilai mata uang rupiah dalam 1 tahun terakhir menunjukkan penurunan nilai rupiah terhadap dollar Amerika yang menyentuh angka disekitar Rp.14.000 per dollar Amerika. Selain itu, dalam 2 tahun terakhir perubahan nilai rupiah terhadap dollar Amerika yaitu disekitar Rp. 13.000 ditahun 2018 dan terus naik signifikan hingga menyentuh angka Rp.15.000. Hal ini dapat kita liat dalam gambar pergerakan mata uang rupiah sebagai berikut:

\section{Gambar 1. Grafik Nilai Mata Uang Dollar Terhadap Rupiah}

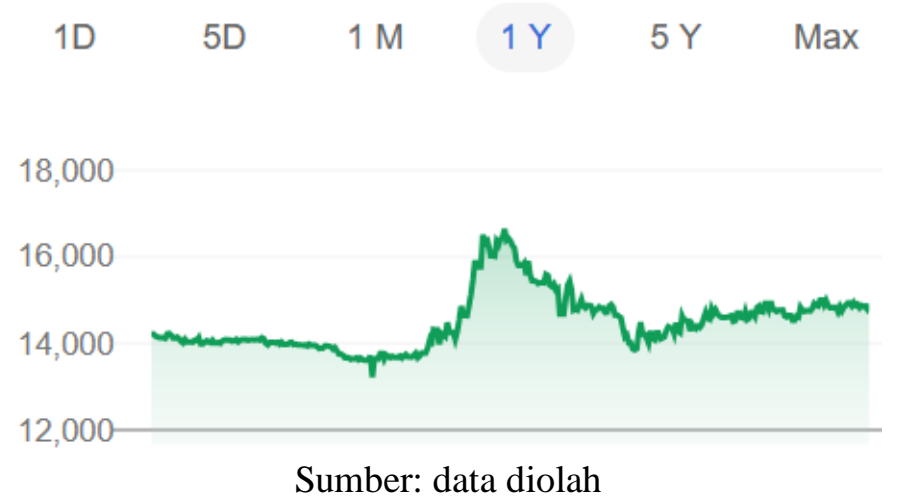

Kinerja emas sendiri dalam kurun waktu 1 (satu) semester tahun 2020 menyentuh angka 4,6\%, dalam waktu setahun telah mencapai 30\% dan dalam kurun waktu 5 (lima) 
tahun terakhir telah menyentuh angka $81 \%$. Artinya kinerja emas dari tahun ke tahun terus merangkak naik walaupun dalam 30 hari terakhir di semester kedua mengalami kontraksi $-3,7 \%$ namun hal tersebut tidak menyurutkan kinerja emas.

Gambar 2. Kinerja Harga Emas dalam Rupiah

\begin{tabular}{|c|c|c|}
\hline \multicolumn{3}{|c|}{ Kinerja Harga Emas IDR } \\
\hline Change & Amount & $\%$ \\
\hline Today & +211225.06 & +0.76 \\
\hline 30 Days & -1050932.44 & -3.64 \\
\hline 6 Months & +1217214.44 & +4.58 \\
\hline 1 Year & +6450704.42 & +30.20 \\
\hline 5 Years & +12403529.47 & +80.52 \\
\hline 20 Years & +25422477.23 & +1065.73 \\
\hline
\end{tabular}

Kondisi covid-19 yang membuat kepanikan seluruh dunia terutama dalam hal yang terkait dengan perekonomian membuat pengaruh yang cukup signifikan terhadap kinerja harga emas. Sejak covid-19 mulai mewabah di akhir tahun 2019 dan kemudian masuk ke Indonesia sekitar bulan januari 2020 menyebabkan kepanikan masyarakat untuk segera mengamankan hartanya. Emas menjadi salah satu pilihan investasi ditengah pandemi tersebut. Sehingga harga emas yang hanya terpaut pada harga disekitar Rp. 650.000 pada bulan desember 2019 terus merangkak naik ditahun 2020 hingga menyentuh angka diatas Rp. 1.000.000.

Gambar 3. Kinerja Harga Emas Tahun 2020.

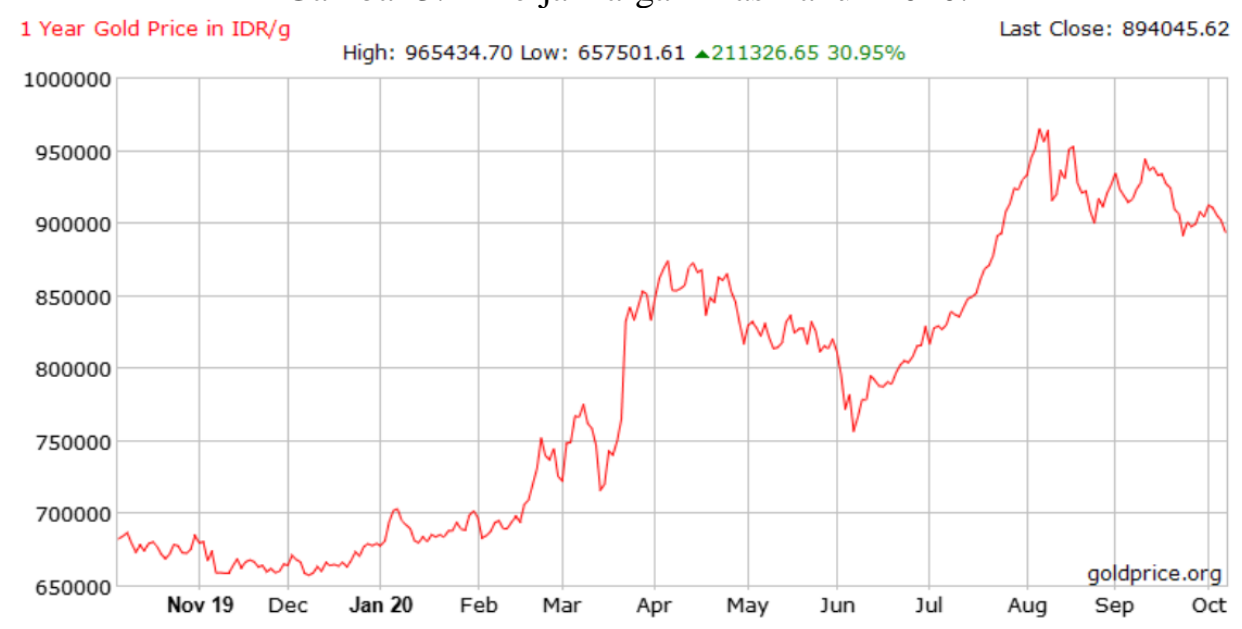

Sumber: Goldprice.org

Redenominasi sendiri telah dimasukkan dalam Program Legislasi Nasional (Prolegnas) jangka menengah 2020-2024. Rancangan Prolegnas terkait dengan perubahan harga rupiah dimana urgensi pembentukan RUU ini untuk menciptakan efisiensi perekonomian berupa percepatan waktu transaksi, berkurangnya resiko human error, dan efisiensi pencantuman harga barang atau jasa karena sederhananya jumlah digit rupiah (Pasardana.id n.d.). 


\section{Pembahasan}

Terdapat integrasi dan ketergantungan disektor perekonomian pada berbagai negara di belahan dunia. Seperti halnya keterkaitan nilai kurs mata uang di berbagai negara. Hal tersebut dipengaruhi oleh aspek perdagangan dan jasa internasional yang terjadi pada negara-negara yang terkait (Abel et al. 2004). Sehingga ketika berubahnya kondisi ekonomi suatu negara akan turut mempengaruhi negara lainnya yang memiliki keterikatan hubungan dengan negara yang terdampak. Misalnya, covid-19 yang telah mewabah di negara Cina di tahun 2020, telah memaksa roda perekonomian negara tersebut untuk berhenti berputar. Padahal tahun 2020 merupakan momentum Cina untuk terus berekspansi. Covid-19 telah memberikan konstraksi yang sangat dalam dalam berbagai aspek perekonomian di negara-negara yang terdampak. Akibat dari kondisi covid-19, pemerintah harus menunda proses redenominasi dan fokus kepada penyelesaian wabah tersebut.

Hal ini sejalan dengan pergerakan nilai mata uang rupiah yang turut kontraksi akibat adanya kejadian wabah pandemi covid-19 tersebut. Memasuki semester kedua nilai rupiah terhadap dollar Amerika terus terkoreksi hingga nyaris menyentuh angka Rp. 15.000. Akibatnya inflasi tidak dapat terbendung dan menyebabkan kenaikan harga barang dan jasa. Sehingga fokus pemerintah berubah 360 derajat terkait dengan proyeksi ekonomi yang telah direncakan di tahun 2019 dalam menyambut tahun 2020. Pada akhirnya pemerintah harus fokus menyelesaikan permasalahan pandemi ini.

(Fei and Adibe 2010) mengemukakan bahwa masyarakat masih menyandingkan emas dengan kurs dollar Amerika, sedangkan performa emas dalam kurun waktu 30 tahun terakhir terus merangkak naik. Walaupun terjadi kontraksi dibeberapa bulan, namun secara esensi emas akan bernilai tetap sesuai dengan kadar yang terkandung didalamnya (Goldprice.org n.d.). Hal ini justru bertentangan bahwa emas hanya dipandang sebagai pelindung nilai (save haven), namun emas dapat dijadikan sebagai sarana investasi jangka Panjang. Emas tidak dapat dijadikan investasi jangka pendek karena harganya cenderung stabil dalam jangka waktu tersebut. Hasil penelitian menunjukkan bahwa emas dapat dijadikan sebagai lindung nilai personal atau individu, bahkan dapat digunakan oleh perusahaan dalam jangka Panjang untuk mengantisipasi kejadian seperti wabah covid-19 ini.

\section{KESIMPULAN}

Penelitian ini memberikan perspektif terkait kondisi perekonomian saat ini yaitu sebagai berikut:

1. Proses redenominasi merupakan sebuah urgensi dalam menciptakan efisiensi dan perbaikan kondisi ekonomi suatu negara. Akan tetapi, wabah covid-19 yang hadir menyebabkan kontraksi pada berbagai sektor ekonomi hamper diseluruh dunia. Sehingga langkah tepat dalam proses redenominasi adalah menunda terlebih dahulu setelah terdapat perbaikan kondisi ekonomi.

2. Nilai mata uang terhadap yang terjadi saat ini ternyata sangat dipengaruhi pula oleh kondisi pandemi covid-19. Sehingga diperlukan langkah antisipasi untuk 
menyiapkan anggaran proyeksi ditahun yang akan datang. Sehingga pemerintah di berbagai negara akan lebih siap dalam kondisi apapun.

3. Emas cenderung dijadikan sebagai sarana investasi dan lindung nilai (save haven). Hal ini terbukti ketika terjadi kondisi covid-19 ternyata harga emas melambung tinggi hingga menyentuh kinerja 30\% dalam kurun waktu 1 (satu) tahun.

4. Emas perlu dipertimbangkan bagi perusahaan dalam menyikapi kondisi seperti saat ini. Emas dapat dijadikan perusahaan sebagai simpanan dan lindung nilai guna persiapan di masa yang sulit seperti kondisi pandemi covid-19.

\section{SARAN}

Penelitian ini masih dalam taraf kajian analisis deskriptif terkait teori ekonomi terkait dan berita terupdate dari berbagai referensi ilmiah lainnya. Lebih lanjut penelitian lainnya dapat melihat dampak perekonomian lebih mendalam ditengah masyarakat ataupun dampak signifikannya terhadap kesejahteraan masyarakat.

\section{UCAPAN TERIMA KASIH}

Penulis mengucapkan terima kasih kepada STIE NOBEL Makassar yang telah memberikan kesempatan untuk penerbitan karya ilmiah ini. Terima kasih pula kepada Orang tua yang senantiasa memberikan dorongan untuk terus menulis karya ilmiah dan belajar. Serta keluarga (Istri dan Anak) yang senantiasa memberikan semangat dalam menambah khasanah pengetahuan. Dan kepada Universitas Muhammadiyah Makassar, yang telah memfasilitasi setiap usaha penulis dalam penerbitan karya Ilmiah.

\section{DAFTAR PUSTAKA}

Abel, Andrew B, Ben S Bernanke, Esther Rabasco, and Luis Toharia. 2004. Macroeconomía. Pearson España.

Asseery, Ahmed, and David A Peel. 1991. "The Effects of Exchange Rate Volatility on Exports: Some New Estimates.” Economics letters 37(2): 173-77.

Baldwin, Richard E, and Virginia Di Nino. 2006. Euros and Zeros: The Common Currency Effect on Trade in New Goods. National Bureau of Economic Research.

Chang, Eric, Ray Y Chou, and Edward F Nelling. 2000. "Market Volatility and the Demand for Hedging in Stock Index Futures." Journal of Futures Markets: Futures, Options, and Other Derivative Products 20(2): 105-25.

Fahmi, Irham. 2012. “Manajemen Investasi: Teori Dan Soal Jawab.” Jakarta: Salemba Empat.

Fei, Fan, and Kelechi Adibe. 2010. "Theories of Gold Price Movements: Common Wisdom or Myths?” Undergraduate Economic Review 6(1): 5.

Gathering, Business. "Menciptakan Momentum Pertumbuhan Ekonomi Sulawesi 
Selatan Untuk Indonesia Maju.”

Goldprice.org. "Goldprice.Org." https://goldprice.org/id/spot-gold.html.

Indonesia, Bank. 2010. Laporan Bank Indonesia.

Kesumajaya, I W W. 2011. "Redenominasi Mata Uang Rupiah Merupakan Bagian Dari Tugas Bank Indonesia Untuk Mengatur Dan Menjaga Kelancaran Sistim Pembayaran Di Indonesia." GaneC Swara 5(1): 1-6.

Keuangan, Kementerian. 2013. "Nota Keuangan Dan Rancangan Anggaran Pendapatan Dan Belanja Negara (NK-RAPBN).”

Krugman, Paul R, Kenneth S Rogoff, Stanley Fischer, and William J McDonough. 1999. "Currency Crises." In International Capital Flows, University of Chicago Press, 421-66.

Lianto, Johan, and Ronald Suryaputra. 2012. "The Impact of Redenomination in Indonesia from Indonesian Citizens' Perspective." Procedia-Social and Behavioral Sciences 40: 1-6.

Mosley, Layna. 2005. "Dropping Zeros, Gaining Credibility? Currency Redenomination in Developing Nations." In 2005 Annual Meeting of The American Political Science Association, Washington DC, Citeseer.

Mukherjee, Ms Pallabi, and Kanhaiya Ahuja. "Real Exchange Rate Volatility and Its Impact on Exports: An Evidence From India."

Pasardana.id. "Menkeu Usulkan Redenominasi Rupiah Masuk Prolegnas 2020-2024.” https://pasardana.id/news/2020/7/13/menkeu-usulkan-redenominasi-rupiah-masukprolegnas-2020-2024/.

Permana, Sony Hendra. 2015. "Prospek Pelaksanaan Redenominasi Di Indonesia." Jurnal Ekonomi \& Kebijakan Publik 6(1): 109-22.

Republik Indonesia, Bapenas. 2019. "PERATURAN MENTERI PERENCANAAN PEMBANGUNAN NASIONAL/KEPALA BADAN PERENCANAAN PEMBANGUNAN NASIONAL REPUBLIK INDONESIA NOMOR 5 TAHUN 2019 TENTANG TATA CARA PENYUSUNAN RENCANA STRATEGIS KEMENTERIAN/LEMBAGA TAHUN 2020-2024."

Stone, Patricia W, Deborah Braccia, and Elaine Larson. 2005. "Systematic Review of Economic Analyses of Health Care-Associated Infections." American journal of infection control 33(9): 501-9.

Suselo, Sri Liani, Hilde Dameria Sihaloho, and Tarsidin Tarsidin. 2008. "Pengaruh Volatilitas Nilai Tukar Terhadap Pertumbuhan Ekonomi Indonesia.” Buletin 
AkMen

Ekonomi Moneter dan Perbankan 10(3): 181-221.
Volume 17 Nomor 4 Desember 2020

Hal. 529 - 547

e-ISSN : 2621-4377 \& p-ISSN : 1829-8524

Hbmepage: https//e-jurnal.stiendbel-indonesiaacid/indexphp/akmen 